\title{
Lexicon of Uma Baloko Establishment of Kodi Speech Community of Southwest Sumba
}

\author{
Paulina Maria Yovita Kosat and Mirsa Umiyati \\ Magister Linguistic, Postgraduated Program, Universitas Warmadewa, Denpasar-Bali, Indonesia \\ jovin.kosat77@yahoo.com

\begin{tabular}{|l|l|}
\hline Received: 24/05/2018 & Revised: 21/07/2018 \\
\hline How to cite (in APA style): & Published: 31/10/2018 \\
Kosat, P, M, Y.(2018).Lexicon of Uma Baloko Establishment of Kodi Speech Community of Southwest Sumba. RETORI- \\
KA: Jurnal Ilmu Bahasa, 4(2), 113-121. doi: http://dx.doi.org/10.22225/jr.4.2.742.113-121
\end{tabular}

\begin{abstract}
Studies on interrelation and interplaying between ecology and language of human have long been of heated debate. Mostly they remain in how linguistic forms are indirectly used within the environment to record all kinds of activities. This study examines the lexicons and their sense relation used in the construction of Uma Bokolo of Kodi speech community, Southwest Sumba, from the perspective of ecolinguistic theory. Data were collected by observing the house and deep-structurally interviewing two senior inhabitants of Kodi. Data analysis was done by tringulation method. The results show that there are 55 lexicons consisting of 41 lexicons of noun-formed and 14 lexicon verb-formed. Each of these lexicons is divided into two categories, namely the category of biotic and abiotic environments. In addition, from the results of the data analysis, it is also found that there are 23 noun lexicon of base form and 17 of compound word form. Each of the lexicon comprises 12 lexicons with N-N pattern, 2 lexicons with $\mathrm{N}-\mathrm{V}$ pattern, and 3 lexicons patterned $\mathrm{N}-\mathrm{A}$. There are three kinds of sense relation found, such as hyponymy, synonymy and hypernymy.
\end{abstract}

Keywords: Ecolinguistic; Lexicon; Sense Relation; Uma Baloko

\section{INTRODUCTION}

Traditional houses reflect the cultural and customary characteristics of the community recorded through language. These houses belong to the environments where humans are and live to carry out all their activities (Alexander \& Stibbe, 2014). All human activities in the environment where they survive are recorded in language to be communicated to others (Mühlhäusler, 2006). Therefore, linguistic studies have examined a lot about the interrelation between humans and their culture, between humans and their environments, and between the human environment and the language they use. One of the sciences that detail the interconnection between the environment and human language is ecolinguistics. From an ecolinguistic perspective, studies on various aspects of human life have been carried out within last two decades (Fill, Alvin \& Mühlhäusler, 2004; Mühlhäusler, 2006; Feng \& Fan, 2012; Finke, 2014; Eliasson, 2015; Chen, 2016). Among these studies, however, viewing how linguistic forms appear in human creations, including traditional houses was not once touched.

In many groups of community in Indonesia, such as Kodi, house is the featuring unique characteristic of Kodi society which is mostly culturally used as a sacred place (Hariyanto, Nurdiah, Asih, \& Tulistyantoro, 2012). Kodi is administratively a small part of Esat Nusa Tenggara area. The life of inhabitants of East Nusa Tenggara is inseparable to traditional houses which are the part of its culture. Traditional houses have become a habit that characterizes the identity of the society; especially in this study is the Regency of Kodi (Fowler, 2005; Hariyanto et 
al., 2012) . Kodi traditional houses of Southwest Sumba have a typical characteristic that lies in the form of a high roof with a structure system that uses local materials and human labor to build. This traditional house has its own uniqueness and attractiveness to be examined in terms of local materials used to build custom houses, of how to take local materials to build custom houses, and the function of each local material to build traditional houses. All of these are the wealth of lexicon for Kodi community. This human cultural phenomenon has its own values and environmental values that are not spared from its relation to language usage. Humans interact with the environment through actions or activities carried out on the surrounding in which it is located (Nash \& Mühlhäusler, 2014). This interaction triggers the existence of a language to record and describe human actions and natural events.

At the aspect of language, a number of studies have been conducted on Kodi. Studies conducted from a typology point of view have been carried out for its imperfective construction (Kodi \& Daya, 2013; Nyoman, Sukerti, Ate, \& Bali, 2016). In terms of its, phonological rules, Kodi language has also been examined to describes its distinctive features (Ekayani, 2016). Additionally, under dialectology study, it has quantitatively been examined in terms of determining its nature of dialect and neighborhood (Budasi, 2017). Kodi language had also been investigated to describe its problem of maintenance (Mbete, 2015). In other words, these previous studies partly deal only with internal construction of the Kodi language and also ekolingustically describe the maintenance and problems in the maintenance. Meanwhile, traditional houses which should be believed as the potential concrete culture of the community involving unique characteristic which languistically can be described should worth of studies, as strategic way to approach the language to the environment.

The present study seeks to recommend an approach of maintaining the language ecolinguistically, particularly those linguistic forms used in the traditional house construction. The approach is implemented by applying descriptive inventory of the language at the initial stage, and then to provide detail information of how the local community discovered to conventionally formulate the linguistic form used as to record their activities and the tools used in the traditional houses. This is due to the nature of ecolinguistic study as an interdisciplinary language science that matches ecology and linguistic in its assessment (Mbete, 2008). Therefore, paper aims to examine the forms of eco-lexicons that arise in the construction of traditional houses in Kodi, Southwest Sumba; examine the functions and meanings of the lexicons; customary home lexicon functions using ecolinguistic theory. The lexicon is examined using an ecolinguistic model in the form of a dialectical hierarchy model, a referential model, and a semantic matrix model, while functions and meanings are assessed using a logical dimension model.

\section{METHOD}

This study was conducted in Kodi East Nusa Tenggara. The data was collected through interviewing 20 participants; including 18 men aged 20 to 40 years and 2 rato 'customary advisers'. All 18 participants were people who had been involved in the construction of traditional houses. In addition, the determined participants were believed to have good mastery of the Kodi language and of the terms used in naming each tool and building material. This participant was given a question about the process of building a traditional house and the materials used for it. All questions given have been prepared before the interview process takes place. After these data were collected, the processing was done by sorting between the used and unsued data. This was done because not all responses given by participants were crucial for this study, so the reduction process was carried out. After that, the selected data was classified according to their linguistic forms and categories, including separating between nouns and verbs. Then, every word that has been sorted out is explained descriptively to provide linguistic information. The data is also displayed in the table to show the condition of words in the form of nouns, verbs, phrases, and categories based on their ecology. After all that was done, the functions and philosophical meanings are explained to show the limits of its ecolinguistic studies. Conclusion withdrawal is the last activity carried out.

\section{III.DISCUSSION}

Uma bokolo 'traditional house' of Kodi community is one of traditional houses which have uniqueness and philosophical meaning for local community that until now it is continuously preserved. Traditional house is built from traditional local materials and human labor. The establishment of this 
traditional house is not arbitrarily done but determined by Rato 'customary advocate'. In establishing the uma bokolo there are traditional speeches and custom rituals which are not free of any ornament of meaning, especially the expression conveyed by Rato when giving the offerings to Marapu are ro utta 'betel nut', hanggi 'kain', wiha 'beras ', kabiyo 'meat', manu 'chicken', wawi 'pig' for a blessing. This kind of adat phrase aims to establish the time of establishment of traditional house by inviting the members of bergotongroyo community and the adat expression also aims to worship the ancestral home to request blessing from the ancestors so that the establishment of custom house can go well.

\section{Noun Lexicon}

The diversity of the lexicon in the establishment of traditional houses in the Kodi, Southwest Sumba people is recently late is apprehensive. Many young people do not know the meaning of these lexicons. This is due to the development of modern currents that encourage the younger generation to put aside their culture. It is feared that the lexicons in the traditional house will become extinct over time.

There are 55 lexicons in the establishment of the traditional house of Kodi society which consists of 41 lexicons categorized as nouns and 14 lexicons categorized as verbs.

Table 1. Noun Lexicon Categorization

\begin{tabular}{|c|c|c|c|c|c|}
\hline \multirow[t]{2}{*}{ No. } & \multicolumn{3}{|c|}{ Lexicon } & \multicolumn{2}{|c|}{$\begin{array}{c}\text { Ecological Catego- } \\
\text { ry }\end{array}$} \\
\hline & Kodi Langauge & English & Latin & Biotic & Abiotic \\
\hline 1 & $U m a$ & House & - & - & + \\
\hline 2 & Uma bokolo & Large house & - & - & + \\
\hline 3 & Pogha & Pole & - & - & + \\
\hline 4 & Pogha kataku & Main pole & - & - & + \\
\hline 5 & Pogha koro bokolo & Large room pole & - & - & + \\
\hline 6 & Pogha kere pahico & Back pillar & - & - & + \\
\hline 7 & Poga tobolo & Terrace pillar & - & - & + \\
\hline 8 & Karangga & Tower frame & - & - & + \\
\hline 9 & Ngeba & Tower & - & - & + \\
\hline 10 & Halele & Circlet & - & - & + \\
\hline 11 & Каdи ита & House building antlers & - & - & + \\
\hline 12 & Robok & Fireplace & - & - & + \\
\hline 13 & Koro & Room & - & - & + \\
\hline 14 & Peda & Curing place & - & - & + \\
\hline 15 & Katendeng & Bedroom & - & - & + \\
\hline 16 & Pogha katendeng & Bedroom pillar & - & - & + \\
\hline 17 & Binya & Door & - & - & + \\
\hline 18 & Binya kabana & Door for men & - & - & + \\
\hline 19 & Binya warcoyo & Door for women & - & - & + \\
\hline 20 & Katopo & Chopper & - & - & + \\
\hline 21 & Gergaghi motor & Censor & - & - & + \\
\hline 22 & Kataka & Axe & - & - & + \\
\hline 23 & Gergaghi & Saw & - & - & + \\
\hline 24 & Ligih/bahi mbolo & Crowbar & - & - & + \\
\hline 25 & Paneta & Rattan & Calamus axillaris & + & - \\
\hline 26 & Kahikara & Forestry rope & - & + & - \\
\hline 27 & Ghayo & Wood & - & - & + \\
\hline 28 & Ghayo kandimbil & Ironwood & Amaratus caudatus & - & - \\
\hline 29 & Ghayo bahi & Spinach wood & $\begin{array}{c}\text { Eusideroxylin } \\
\text { zwageri }\end{array}$ & - & + \\
\hline 30 & Ghayo karara & Wood & Hibiscus similis $B L$ & - & + \\
\hline 31 & Ongol & Bamboo & $\begin{array}{l}\text { Dendrocalamus as- } \\
\text { per }\end{array}$ & + & - \\
\hline 32 & Potto & Bamboo & $\begin{array}{l}\text { Bambusa arundina- } \\
\text { cea }\end{array}$ & + & - \\
\hline 33 & Handa & Wall & - & - & + \\
\hline 34 & Ngingo & Medium & - & + & - \\
\hline 35 & Pungo ngio & Cocnut tree & Cocos nucifera $L$ & + & - \\
\hline
\end{tabular}




\begin{tabular}{lllccc}
\hline \hline 36 & Pungo labba & Areca nut tree & Areca catechu & + & - \\
37 & Lawa ngio & Block of coconut tree & - & - & + \\
38 & Lawa labba & Block of areca nut tree & - & - & + \\
34 & Ngingo & Alang & - & + & - \\
35 & Pungo ngio & Coconut tree & Cocos nucifera L & + & - \\
36 & Pungo labba & Areca nut tree & Areca catechu & + & - \\
37 & Lawa ngio & Block of coconut tree & - & - & + \\
38 & Lawa labba & Block of areca nut tree & - & - & + \\
39 & Lawiri & Blok & - & - & + \\
40 & Ghayo & Wood & - & - & + \\
41 & Pungo & Tree & - & + & - \\
\hline
\end{tabular}

Based on Table 1, the lexicon of indigenous houses was categorized as no. 41 lexicon. Consisting of two parts of the differentiation environment is the biotic environment and abiotic environment. The lexicon of the noun category in the biotic environment is 8 lexicons and the noun category lexicon in the abiotic environment is 33 lexicons.

Verb Lexicon

Verb lexicon is a form of expression of an object, activity, siatuasi that occurs greeting a guyub said. The lexicon is alive, growing and extinct in a speech society if it is not preserved. Lexicon is an expression of the meaning and value of cultures, customs, and precious habits by the speech society that must be preserved by the modern generation. The verb lexicon in the establishment of the customary kubai house is shown in Table 2.

Table 2 Verba lexicon Categorization

\begin{tabular}{cllccc}
\hline No & Kodi Language & \multicolumn{1}{c}{$\begin{array}{c}\text { Lexicon } \\
\text { English }\end{array}$} & Latin & $\begin{array}{c}\text { Ecological Category } \\
\text { Biotic }\end{array}$ & Abiotic \\
\hline 1 & Rabhiko/kahuko & to pull & & - & + \\
2 & Pogho/teba & to cut down & - & + \\
3 & Ropo/ghoto & to cut & - & + \\
4 & Takki & to set & to dig up & - & + \\
5 & Konda & to stick in & - & + \\
6 & Mbetinntehkin & to make & - & + \\
7 & Pa-ndaha & to tie & - & + \\
8 & Pa-tanna & to close(nomina) & - & + \\
9 & To'di & to weave & - & + \\
10 & Woloya & to build & - & + \\
11 & Pa-kedde & to saw & - & + \\
12 & Gergaghi-ya & to isntall the tower frame & - & + \\
13 & Pa-karangga & to install the reed & - & + \\
14 & Pa-ngeba & & & + \\
\hline
\end{tabular}

Based on the data in Table 2, the lexicons of the verb form in the establishment of the house of Kodi language consists of abiotic environment. It is indicated in (32) which are rabhiko and kahuko 'plant'. The meaning of planting in two lexicons of rabhiko and kahuko is different depending on the context of the use of the lexicon. As in the following clause example: (1) la-rabhiko ngingo la-kandangu 'go to pull the weeds in the forest'; (2) la-rabhiko rumba la-mongo 'go to pull grass in the garden'; (3) kahuko-ya pogha katakku 'pull the main pole'; (4) Kahuko-ya paghu la-pogha 'pull the nail on the pole'. 'Pull' in clauses (1) and (2) includes a noun and categorized biotic environment such as ngingo 'alang', rumba 'grass'. Meanwhile, the meaning of pulling in clauses (3) and (4) is a category of noun words and is categorized as abiotic environment, such as paghu 'paku', pogha 'pole'.

Both lexicons pogha and teba in data (33) have the same meaning but are different in the context of everyday use. It is like pogho lexicon in clauses: (1) pogho-ya pungo ghayo kandimbil 'cut down the ulin tree', (2) pogho-ya pungo kalongho 'cut down the banana tree'. The lexicon in the following clause: (1) henene teba -ya rikoko-na karboyo 'now cut the buffalo's neck off. (2) Teba-ya rikoko-na ndara monno khapi la-parona 'cut the horse's neck and buffalo in the village'. The lexicon pogho in clause (1), (2) means 'to cut down' is of noun form categorized by large biotic (plant) environments, such as; pungo 'tree'. Meanwhile, the lexicon of the clause (3) and (4) means 'to cut down' of noun form categorized as biotic environment (large 
animal), such as; carboyo 'buffalo', ndara 'horse', khapi 'cow'. The use of pogho and teba among Kodi language speech community depends on the context of the use and the target noun object of verbal treatment.

Furthermore, in everyday life, the Kodi community recognizes two ropo and ghoto lexicons meaning to cut with different meanings (data 33). The difference between the two lexicons can be seen in the following clause: (1) ropo-ya manu 'cut' the chicken and let its blood on the ground; (2) ropo-ya rande 'cut the duck'; (3) ghoto-ya kaloro 'cut the rope'. The ropo lexicon in the data (1) and (2) means cutting, of noun form and categorized biotic environments (medium-sized animals and small animals), while the ghoto in data (3) means cutting, categorizing nouns and abiotic environment.

\section{Morphological Form}

In terms of building the traditional house of Kodi society, it is found that there are two forms of morphological processes emerging, namely the basic form and the compound form (Table 3).

\section{Basic Form}

The basic form is the lingual unit, both single and complex, which form the basis of the formation for the larger unit (Ramlan 1985: 45). Meanwhile Chaer (2012: 159) mentions a base is a unit that forms the basis of a morphological process, which means certain affixes can be given in the affixation process, reduplication processes can be repeated or combined with other morphemes in a plural process. The basic form is a single morpheme but can also be a combination of morphemes (cf. Katamba, 1993: 45).

Table 3. Basic Form of Lexicon

\begin{tabular}{|c|c|c|c|c|c|c|}
\hline \multirow[t]{2}{*}{ No. } & \multirow[t]{2}{*}{ Base } & \multirow[t]{2}{*}{ Meaning in English } & \multicolumn{2}{|c|}{$\begin{array}{l}\text { Environmen- } \\
\text { tal Category }\end{array}$} & \multicolumn{2}{|c|}{$\begin{array}{l}\text { Word cate- } \\
\text { gory }\end{array}$} \\
\hline & & & $\begin{array}{c}\text { Bio- } \\
\text { tic }\end{array}$ & $\begin{array}{l}\text { Abi- } \\
\text { otic }\end{array}$ & $\mathbf{N}$ & $\mathbf{V}$ \\
\hline 1 & Uma & Residential building & - & + & + & - \\
\hline 2 & Pogha & Long sticks of wood, bamboo, used to support. & & - & + & - \\
\hline 3 & Karangga & $\begin{array}{l}\text { Eight pieces of petung 'bamboo' made for the skeleton of } \\
\text { the tower }\end{array}$ & - & + & + & - \\
\hline 4 & Ngeba & Tower made of reeds & - & + & + & - \\
\hline 5 & Halele & Wood formed like a bracelet & - & + & + & - \\
\hline 6 & Robok & $\begin{array}{l}\text { Fireplace made of wood, solid soil, and three waiting } \\
\text { stones }\end{array}$ & - & + & + & - \\
\hline 7 & Koro & Room; made of bamboo arrangement into room booth & - & + & + & - \\
\hline 8 & Peda & Curing place & - & + & + & - \\
\hline 9 & Katendeng & Bed made of bamboo & - & + & + & - \\
\hline 10 & Binya & The door is made of bamboo or wood & - & + & + & - \\
\hline 11 & Katopo & Parang; Iron is long and sharp & - & + & + & - \\
\hline 12 & Kataka & Big pickup for cutting timber & - & + & + & - \\
\hline 13 & Ngerghaghi & Wood cutting tool from jagged iron plate & - & + & + & - \\
\hline 14 & Lingih & $\begin{array}{l}\text { A sharp piece of iron tip to dig the ground, splitting the } \\
\text { hard mantle }\end{array}$ & - & + & + & - \\
\hline 15 & Paneta & $\begin{array}{l}\text { A creeping plant whose trunks are used for various pur- } \\
\text { poses }\end{array}$ & + & - & + & - \\
\hline 16 & Kahikara & Long-threaded objects are made to bind, solidify & - & + & + & - \\
\hline 17 & Ghayo & Stem, hard tree branches commonly used for poles, tools & - & + & + & - \\
\hline 18 & Ongol & $\begin{array}{l}\text { Plants that grow berumpun, rooted fibers are hollow round } \\
\text { stems, hard and high (between } 20-30 \mathrm{~cm} \text { ) }\end{array}$ & + & - & + & - \\
\hline 19 & Potto & $\begin{array}{l}\text { Plants that grow with clumps, rooted fibers whose stems } \\
\text { are hollow round, hard and high (between } 20-30 \text { meters) }\end{array}$ & + & - & + & - \\
\hline 20 & Handa & Cover, room divider, booth made of bamboo & - & + & + & - \\
\hline 21 & Ngingo & $\begin{array}{l}\text { Imperata, grass, grass that reaches } 20 \text { to } 150 \mathrm{~cm} \text { high and } \\
\text { large }\end{array}$ & + & - & + & - \\
\hline 22 & Lawiri & $\begin{array}{l}\text { The logs that have been shampooed but not yet made the } \\
\text { board }\end{array}$ & - & + & + & - \\
\hline 23 & Pungo & The plants of hard-trunked & + & - & + & - \\
\hline
\end{tabular}


The data in Table 3 shows that there are 23 lexicons in the form of the base and categorized nouns; lexicons of nouns categorized biotic environment amounted to 6 lexicons; and noun lexicons categorized abiotic environment numbered 17 lexicons.

\section{Lexicon Form and Categorization Embodies into Nominal Phrase}

The noun phrase is a phrase consisting of a noun as a parent and another expansion element having a relationship as subordinate to the parent. This opinion is similar to that expressed by Wedhawati (2001: 201) that the noun phrase is a unit of language formed of two or more words with nouns as the core. In the lexicon of the building of traditional house of Kodi community there are 3 patterns found in 13 data, namely $9 \mathrm{~N}-\mathrm{N}$ patterned data, 2 data with $\mathrm{N}-\mathrm{V}$ pattern, and 2 data with $\mathrm{N}-\mathrm{A}$ pattern.

Table 4. Lexicon Form and Categorization Embodies into Nominal Phrase

\begin{tabular}{|c|c|c|c|c|c|c|}
\hline \multirow[t]{3}{*}{ No. } & \multirow[t]{3}{*}{ Kodi Language } & \multirow[t]{3}{*}{ Meaning in English } & \multicolumn{4}{|c|}{ Constituent Element } \\
\hline & & & \multicolumn{2}{|c|}{ Core } & \multicolumn{2}{|c|}{ Modifier } \\
\hline & & & Lexicon & Category & Lexicon & Category \\
\hline 1 & Uma bokolo & Large house & $U m a$ & $\mathrm{~N}$ & Bokolo & $\bar{A}$ \\
\hline 2 & Pogha kataku & Main hole & Pogha & $\mathrm{N}$ & Kataku & A \\
\hline 3 & Pogha koro bokolo & Bedroom pillar & Pogha & $\mathrm{N}$ & Koro bokolo & A \\
\hline 4 & Pogha kere pahico & Back house pillar & Pogha & $\mathrm{N}$ & Kere pahico & $\mathrm{N}$ \\
\hline 5 & Pogha tobolo & Terrace pole & Pogha & $\mathrm{N}$ & Tobolo & $\mathrm{N}$ \\
\hline 6 & Kadu uma & House antlers & kadu & $\mathrm{N}$ & Uma & $\mathrm{N}$ \\
\hline 7 & Pogha katendeng & Bedroom pole & Pogha & $\mathrm{N}$ & Katendeng & $\mathrm{N}$ \\
\hline 8 & Binya kabana & Door for men & Binya & $\mathrm{N}$ & Kabani & $\mathrm{N}$ \\
\hline 9 & Binya warcoyo & Door for women & Binya & $\mathrm{N}$ & Warcoyo & $\mathrm{N}$ \\
\hline 10 & Gerghagi motor & $\begin{array}{l}\text { Wood cutting tools } \\
\text { made of jagged iron } \\
\text { using the engine as } \\
\text { propulsion. }\end{array}$ & Gerghagi & $\mathrm{N}$ & Motor & $\mathrm{N}$ \\
\hline 11 & Ghayo kandimbil & $\begin{array}{l}\text { Tree plants are large } \\
\text { and textured strong } \\
\text { wood. }\end{array}$ & Ghayo & $\mathrm{N}$ & Kandimbil & $\mathrm{N}$ \\
\hline 12 & Ghayo bahi & $\begin{array}{l}\text { Sized big and strong } \\
\text { tree plant }\end{array}$ & Ghayo & $\mathrm{N}$ & Bahi & $\mathrm{N}$ \\
\hline 13 & Ghayo karara & $\begin{array}{l}\text { Large pohone plant } \\
\text { textured fibrous } \\
\text { wood. }\end{array}$ & Ghayo & $\mathrm{N}$ & Waru & $\mathrm{N}$ \\
\hline 14 & Pungo labba & $\begin{array}{l}\text { The stems of betel } \\
\text { trees are rooted in } \\
\text { fibers. }\end{array}$ & Pungo & $\mathrm{N}$ & $L a b b a$ & V \\
\hline 15 & Pungo ngiyo & $\begin{array}{l}\text { The coconut tree } \\
\text { trunk is rooted in } \\
\text { fibers. }\end{array}$ & Pungo & $\mathrm{N}$ & Ngiyo & $N$ \\
\hline 16 & Lawa ngiyo & $\begin{array}{l}\text { A long beam of co- } \\
\text { conut tree trunk. }\end{array}$ & Lawa & $\mathrm{N}$ & Ngiyo & $\mathrm{N}$ \\
\hline 17 & Lawa labba & $\begin{array}{l}\text { Long beam from the } \\
\text { trunk of arena nut } \\
\text { tree }\end{array}$ & Lawa & $\mathrm{N}$ & $L a b b a$ & V \\
\hline
\end{tabular}

Based on the data in Table 4 lexicon form of compound word has 3 patterns found in 17 data that is 12 data patterned N-N, 2 data patterned $\mathrm{N}-\mathrm{V}$, and 3 data patterned $\mathrm{N}-\mathrm{A}$.

Phrases or compound words that patterned in N-N are: datum (4) pogha kere pahico 'back pole'; datum (5) pogha tobolo 'pole terrace'; datum (6) kadu uma 'house horn'; (7) pogha katendeng 'bed pole'; datum (8) binya kabani 'door for men'; datum (9) binya warcoyo 'door for women'; datum (10) gerghagi motor 'sensor'; datum (11) ghayo kandimbil 'ulin wood'; datum (12) ghayo bahi bahi wood'; datum (18) ghayo karara 'waru wood'; datum (15) pungo ngiyo 'coconut tree'; and datum (16) lawa ngiyo 'coconut trunks'.

Furthermore, N-V-patterned data are found in the data (15) pungo labba in the base form pungo and categorized into noun; labba categorized into verbs. In the datum (17) lawa labba is formed by the basic form lawa with the category of nouns and labba is of verb. The NA patterned datum is found in datum (1) uma bokolo data formed from the uma and adjective large; and datum (2) pogha kataku is formed from noun pogha and adjective kataku; and so 
is for datum (3) pogha koro bokolo 'large room pole'.

\section{Sense Relation}

The lexicons in the Kubi language speakers have a correlation between the relation of semantic meaning and the referred entity. The resulting meaning refers to the form of the lexicon of nouns and the verb lexicon to the identity of the establishment of the custom house of the Kodi society. The relation of meaning in data is seen in the form, function, and meaning of each lexicon. There are three relations of meaning that is contained in the discovered lexicon, such as hyponymy, synonymy, and hipernymy.

\section{Hyponymy}

The relation meaning of hyponymy is the relation of the meaning of an utterance which is included in the meaning of another form of speech. The study of data shows lexicon that has a semantic-type relation of hyponymy. Based on the data obtained, there is a noun uma 'house' taking the highest level or supeordinate over lexicon uma bokolo, uma harri, uma mango. Sense relation that appears in both supeordinate and hyponymy is of one way. Uma, when it is examined in terms of environment, it is originated from abiotic category. Uma bokolo 'big hous' is a place of dwelling ancestral spirits that become similar to the god (marapu). In this house heirloom property of a large family of the house is also stored. Uma harri, the sacred house, is a small house sacred in a village and a center of ceremonies for people trusting to marapu. Uma mongo is a small house located in a garden area and used as a resting place.

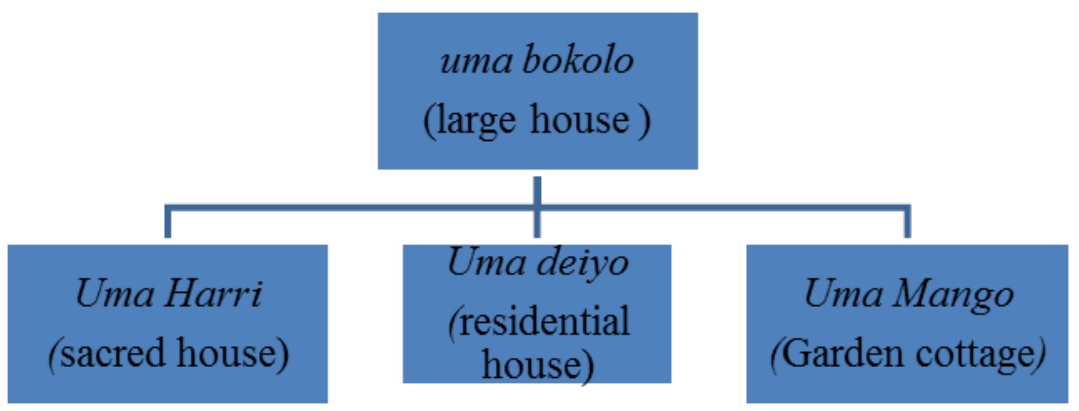

Figure 1. Hyponymy (uma 'rumah')

\section{Synonymy}

Synonymy is a semantic relation that expresses the similarity of meaning between one units of speech with another unit of speech. Referring to the description of Verhaar, it can be said that a synonym is an expression (can be a word, phrase, or sentence) whose meaning is more or less the same as the meaning of another expression. The relationship of meaning between two synonymous words is two-way. Basically, the similarity of the meaning of two synonymous ones is not one hundred percent true, only less; the similarity is not absolute. Synonymous words mean not exactly the same. Though small, the differences between them must exist.

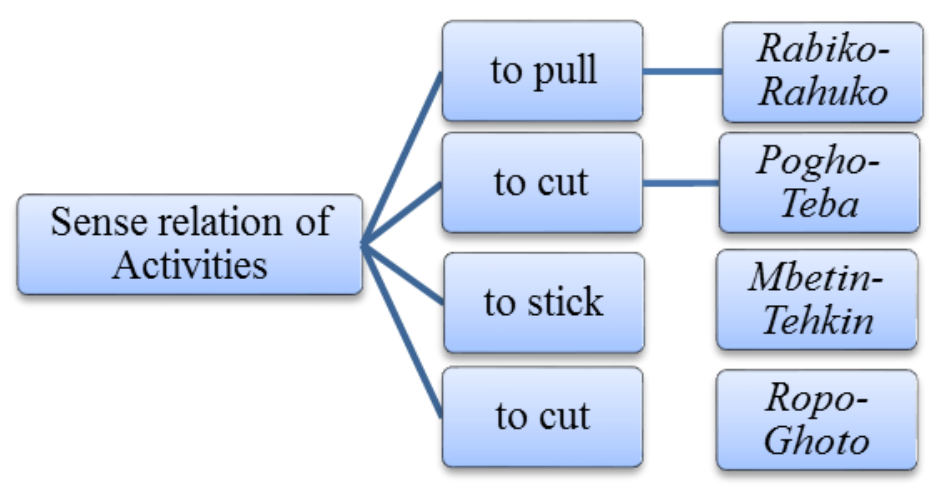

Figure 2. Sense Relation of Establishing Adatar House 


\section{Hypernymy}

Figure 3 displays the lexicon of the names of the tools used in establishing customary traditional houses which are in the row of hypernymy with katopo, gergaji, kataka, gergaghi motor, lingih.

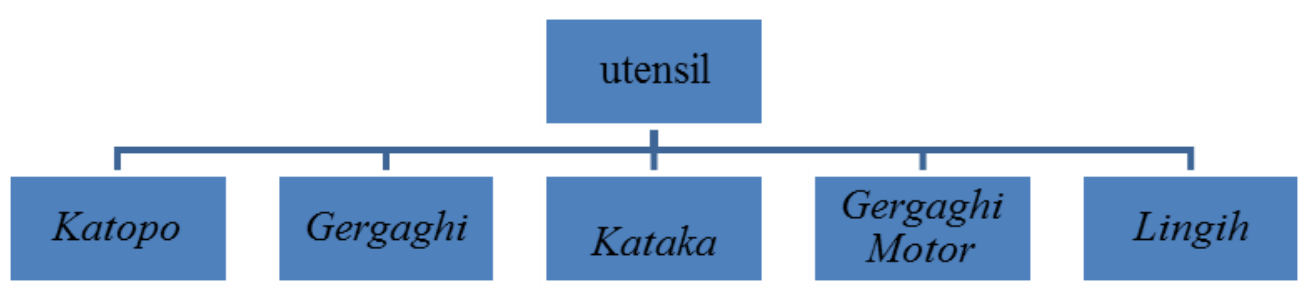

Figure 3. Meaning Relation of Lexicon Used for Establishing Traditional House

\section{IV.CONCLUSION}

This review has examined the lexicons and sense relations within lexicon in the traditional house construction process with the speech community of Kodi. Every entity in every aspect of human life is covered by the meanings and relationship between those meanings with the referred entities. It gives rise to the wealth of lexicons in the process of building the traditional house, here is of Kodi society. This is inseparable from the main role of the environment as a container that shapes it because everything that happens in human life is inspired and done in the environment where the human being is. The type and variety of materials utilized in the traditional house construction by Kodi society reflects that the community often interacts with the surrounding environment, thus triggering the large number of lexicons with names given to them that have philosophical and ideological meaning. Each contained meaning has a hyponymy, synonymy and hypernymy relations. Intimate relation between humans and the environment triggers the formation of philosophy in human life recorded and inherited through language lexicons. Kodi society is an environmental ideology society which is partly reflected through traditional house building which material and process of making not just plagiarism but inspired from natural environment around. This study, however, has discussed the study of ecolinguistics on the level of identification of lexicon forms and relations of meaning. For the object of this study, further studies may be made of it primarily on the way of naming each section and activity in the construction of traditional houses.

Acknowledgement
The author would like to thank Prof. Dr. Aron M. Mbete, who has guided the author and gave the author an opportunity to make this article public. The author would like to thank Prof. Dr. Aron M. Mbete, who has guided the author and gave the author an opportunity to make this article public. Last but not least, the authors would like to express their gratitude to Warmadewa University, especially its journals managers for their willingness to develop their energy, mind and time in editing and launching this scientific work. Hopefully this paper can be useful for every reader.

\section{References}

Alexander, R., \& Stibbe, A. (2014). From the analysis of ecological discourse to the ecological analysis of discourse. Language Sciences, 41, 104-110.

Budasi, I. G. Relasi Kekerabatan Genetis Kuantitatif Isolek-Isolek Sumba di NTT: Sebuah Kajian Linguistik Historis Komparatif (2017).

Chen, S. (2016). Language and ecology: A content analysis of ecolinguistics as an emerging research field. Ampersand, 3, 108-116.

Ekayani, N. P. (2016). Sistem fonologi bahasa kodi di pulau sumba. Universitas Udayana, 1-18.

Eliasson, S. (2015). The birth of language ecology: Interdisciplinary influences in Einar Haugen's "The ecology of language." Language Sciences, 50(April 2013), 78-92.

Feng, R., \& Fan, A. (2012). A Brief Analysis on the Lettered Words in Chinese--From the Perspective of Ecolinguistics. IERI Procedia, 2, 194-199.

Fill, Alvin \& Mühlhäusler, P. (2004). The Ecolinguistics: Language Reader, Ecology, and Environment. Language and Communication, 24(4), 183-205. 
Finke, P. (2014). The ecology of science and its consequences for the ecology of language. Language Sciences, 41, 71-82.

Fowler, C. (2005). WHY IS MAIZE A SACRED PLANT? SOCIAL HISTORY AND AGRARIAN CHANGE ON SUMBA, 25(1), 39-57.

Hariyanto, A. D. A., Nurdiah, A., Asih, E., \& Tulistyantoro, L. Hubungan Ruang, Bentuk dan Makna pada Arsitektur Tradisional Sumba Barat: Laporan Penelitian (2012).

Kodi, P., \& Daya, S. B. (2013). Konstruksi keaspekan imperfektif progresifbahasa kodi, sumba barat daya, (1), 1-12.

Mbete, A. M. (2008). Ekolinguistik: Perspektif Kelinguistikan yang Prospektif. Bahan Kuliah Matrikulasi Program Magister Linguistik PPs Universitas Udayana. Denpasar.

Mbete, A. M. (2015). Masalah Kebahasaan dalam Kerangka Pelestariannya: Perspektif Ekolinguistik. Jurnal Tutur, 1(2), 181-188.

Mühlhäusler, P. (2006). Environment and Language. Encyclopedia of Language \& Linguistics, 203-207.

Nash, J., \& Mühlhäusler, P. (2014). Linking language and the environment: The case of Norf'k and Norfolk Island. Language Sciences, 41, 26-33.

Nyoman, G., Sukerti, A., Ate, Y. G., \& Bali, P. N. (2016). POLA PEMARKAHAN ARGUMEN BAHASA KODI, (2), 129-145. 